\title{
Nutritional status induces divergent variations of GLUT4 protein content, but not lipoprotein lipase activity, between adipose tissues and muscles in adult cattle
}

\author{
Muriel Bonnet ${ }^{1}$, Yannick Faulconnier ${ }^{1}$, Jean-François Hocquette ${ }^{1}$, François Bocquier ${ }^{1} \dagger$, \\ Christine Leroux ${ }^{1,2}$, Patrice Martin ${ }^{2}$ and Yves Chilliard ${ }^{1 *}$ \\ ${ }^{1}$ INRA, Unité de Recherches sur les Herbivores, Theix, 63122 Saint-Genès-Champanelle, France \\ ${ }^{2}$ INRA, Laboratoire de Génétique Biochimique et de Cytogénétique, Domaine de Vilvert, 78352 Jouy-en-Josas, France
}

(Received 17 March 2004 - Revised 10 June 2004 - Accepted 10 June 2004)

\begin{abstract}
Metabolic adaptations to variations in food supply are incompletely understood in ruminant animal adipose tissue (AT) and muscle. To explore this, we studied lipid metabolism and glucose transport potential in one internal and one external AT, as well as in one oxidative and one glycolytic muscle from control, $7 \mathrm{~d}$ underfed and $21 \mathrm{~d}$ refed adult cows. Refeeding increased $(+79$ to $+307 \%)$ the activities of enzymes involved in de novo lipogenesis (fatty acid synthase, malic enzyme, glucose-6-phosphate dehydrogenase) in perirenal and subcutaneous AT; underfeeding did not modify these variables. Underfeeding decreased the activities of lipoprotein lipase (LPL) in perirenal AT $(-70 \%)$ and cardiac muscle $(-67 \%)$, but did not modify the activities in subcutaneous AT and longissimus thoracis. Refeeding increased LPL activities in all tissues $(+40$ to $+553 \%$ ) to levels comparable with (cardiac muscle) or greater than (AT, longissimus thoracis) those observed in control cows. Such variations in perirenal and cardiac muscle LPL activities did not result from variations in LPL mRNA levels, but suggest a post-transcriptional regulation of LPL in these nutritional conditions. Underfeeding did not modify GLUT4 contents in perirenal AT and muscles, while refeeding increased it only in perirenal AT $(+250 \%)$. Our present results contrast with previous results in rats, where LPL is regulated in opposite directions in AT and muscles, and GLUT4 is generally increased by fasting and decreased by refeeding in skeletal muscles. The present results highlight the bovine specificity of the response, which probably arises in part from peculiarities of ruminant animals for nutrient digestion and absorption.
\end{abstract}

Lipogenesis: GLUT4: Adipose tissue: Muscle: Adult cattle

Most domestic ruminant animals are subjected to variations in energy intake induced mainly by seasonal variations in food supply for economic or husbandry reasons. Midterm (few weeks) variations in energy intake are characterised by changes in nutrient availability and metabolism by peripheral tissues (Chilliard et al. 2000). However, the variations in the activities of the key metabolic pathways ensuring these adaptations have not been fully identified. This is the case for the lipogenic activities of adipose tissues (AT), which have been mainly studied up to now during fasting and refeeding. It is widely acknowledged that refeeding underfed or fasted ruminant animals increases the level of lipogenesis to values similar to or greater than those in control animals (Pothoven \& Beitz, 1975; DiMarco et al. 1981; Smith et al. 1983; Tume et al. 1983; Bocquier et al. 1998; Bonnet et al. 1998; Faulconnier et al. 2001). However, there is less agreement about the fasting effect on the activities of enzymes involved in de novo lipogenesis, since the decreases reported were not always statistically significant (Young et al. 1969; Ingle et al. 1973; Martin et al. 1973; Pothoven \& Beitz, 1973, 1975; Smith et al. 1983). Likewise, the ability of ruminant animal muscles to hydrolyse, via lipoprotein lipase (LPL), circulating triacylglycerol (TG) during underfeeding and refeeding was only studied in ewes and was different from that reported in rodents. We have reported that underfeeding decreased and refeeding increased LPL activities in oxidative (Bonnet et al. 2000) and glycolytic (Faulconnier et al. 2001) muscles from ewes, while the reverse was reported in rats (Quig et al. 1983; Sugden et al. 1993). These results suggest a particular adaptation of muscle LPL in ewes, which remains to be studied in other ruminant animal species, such as cattle. Finally, glucose utilisation in adult ruminant animals during underfeeding and refeeding has never been addressed. In ruminant animals, peripheral tissues, and especially muscles by virtue of their mass, are the major consumers of glucose (Pethick, 1984). The rate-limiting

Abbreviations: AT, adipose tissue; CM, cardiac muscle; FAS, fatty acid synthase; G3PDH, glycerol-3-phosphate dehydrogenase; G6PDH, glucose-6phosphate dehydrogenase; LPL, lipoprotein lipase; LT, Longisimus thoracis; ME, malic enzyme; TG, triacylglycerol.

* Corresponding author: Dr Y. Chilliard, fax + 334736245 19, email Yves.Chilliard@clermont.inra.fr

$\dagger$ Present address: ENSAM-INRA Productions Animales, 2 Place Viala, 34060 Montpellier Cedex, France. 
step in glucose utilisation in bovine AT and muscles is glucose transport rate (Hocquette et al. 1995) as in rodents. Glucose transport in AT and muscle is carried out by two facilitative glucose transporters: insulin-sensitive GLUT4, and non-insulin-sensitive GLUT1. However, in rodents GLUT4 seems to play a major role in enhancing glucose transport in response to insulin in AT and muscles, while GLUT1 plays a minor role (Kahn, 1994).

Hence, to address the issue of glucose transport and to complete available data on lipid metabolism in AT and in both oxidative and glycolytic muscles, we assayed enzymes activities and transporter protein contents involved (during underfeeding and refeeding in adult cattle) in: (1) de novo lipogenesis (fatty acid synthase (FAS), glucose-6-phosphate dehydrogenase (G6PDH), malic enzyme (ME)); (2) fatty acid esterification (glycerol-3-phosphate dehydrogenase (G3PDH)); (3) hydrolysis of TG-rich lipoproteins (by LPL); (4) glucose transport regulated by insulin (GLUT4).

\section{Materials and methods}

\section{Animals and diets}

The present study was carried out in compliance with the French recommendations and with the Animal Care and Use Committee of the Institut National de la Recherche Agronomique (INRA) for the use of experimental animals, including animal welfare and appropriate conditions (guidelines 18 April 1988). Adult non-lactating non-pregnant Holstein cows ( $n$ 13) were allotted to one of three groups: control, underfed, refed. During the pre-experimental period, in order to prevent any putative onset of oestrus in some cows, all cows were treated with intravaginal sponges containing progesterone (PRID, $2 \mathrm{~mm}$; Sanofi, Libourne, France). During the experimental period, cows received a control diet for 4 weeks, providing $130 \%$ maintenance energy requirement calculated on the basis of $0.4 \mathrm{MJ}$ metabolisable energy $/ \mathrm{kg}$ body weight ${ }^{-075}$ per d (Insitute National de la Recherche Agronomique, 1989). Four cows (control group) were slaughtered, while the remaining nine cows were underfed to $21 \%$ maintenance energy requirement for $7 \mathrm{~d}$. Four cows (underfed group) were slaughtered at the end of the underfeeding period, while the remaining five cows were refed at $237 \%$ maintenance energy requirement for $21 \mathrm{~d}$ (refed group) until slaughtering. Underfeeding (7d) and refeeding (21d) experiments were chosen because earlier experiments (Pothoven \& Beitz, 1975; DiMarco et al. 1981) had shown that 4-8d are required to achieve a fasting state, and about $20 \mathrm{~d}$ to restore lipogenic activities to pre-fasting rates. The diet of the control group consisted of hay-barley grain $(69: 31, \mathrm{w} / \mathrm{w})$. The diet of the underfed group consisted of hay-straw $(60: 40$, w/w). The diet of the refed group consisted of hay-concentrate (49:51, w/w). The concentrate $(\mathrm{g} / \mathrm{kg})$ consisted of: maize 190, sugarbeet pulp 300, soyabean meal 416, molasses 20 , fish meal 50 , vitamin-mineral premix 24 . The vitamin-mineral premix $(100 \mathrm{~g} / \mathrm{d})$ was added to the diet of each group and contained (per kg): $\mathrm{Ca} 150 \mathrm{~g}, \mathrm{P} 100 \mathrm{~g}, \mathrm{Mg}$ 20 g, Na 30 g, S 10 g, Zn 8000 mg, Mn $6000 \mathrm{mg}$, I $50 \mathrm{mg}$, Co $10 \mathrm{mg}$, Se $10 \mathrm{mg}$, retinyl acetate $86 \mathrm{mg}$, cholecalciferol $1.25 \mathrm{mg}, \quad \alpha$-tocopherol $134 \mathrm{mg}$, thiamin hydrochloride $21 \mathrm{mg}$. Diets were offered to the control and underfed groups at 10.00 hours, and to the refed group at 10.00 and 15.00 hours (the ration was divided into two equal portions). Cows had free access to water. Offered feeds and refusals were recorded daily and the daily intake of each animal was calculated (Table 1). After slaughter (at about 09.00 hours on the day following the last meal), samples of subcutaneous and perirenal AT, cardiac muscle (CM) and longissimus thoracis muscle (LT) were immediately placed at $37^{\circ} \mathrm{C}$ for adipocyte volume determination or frozen in liquid $\mathrm{N}_{2}$ until measurement of DNA and protein content, enzyme activities, LPL mRNA level and GLUT4 protein content.

\section{Plasma measurements}

Blood samples were collected from the jugular vein the day before slaughter, at 09.00 and at 14.00 hours for the determination of plasma insulin (INSI-PR RIA kit; CIS Bio International, Gif-sur-Yvette, France) and metabolite concentrations. Plasma levels of glucose, acetate, TG, urea, $\beta$-hydroxybutyrate, NEFA, non-esterified glycerol and lactate were determined with an ELAN auto-analyser (Merck-Clévenot SA, Nogent-sur-Marne, France) by spectrophotometric enzymic assays, as described by Ferlay \& Chilliard (1999) using specific kits (Glucose S-system

Table 1. Ingredients, energy and protein ingested daily by control, underfed and refed cows* (Mean values with their standard deviations)

\begin{tabular}{|c|c|c|c|c|c|c|c|}
\hline \multirow{2}{*}{ Nutritional status...† } & \multicolumn{2}{|c|}{ Control } & \multicolumn{2}{|c|}{ Underfed } & \multicolumn{2}{|c|}{ Refed } & \multirow{2}{*}{$\begin{array}{c}\text { Statistical significance } \\
\text { of effect: } P \ddagger\end{array}$} \\
\hline & Mean & SD & Mean & SD & Mean & SD & \\
\hline $\mathrm{DM}(\mathrm{g} / \mathrm{d})$ & $8170^{a}$ & 740 & $2000^{c}$ & 90 & $14680^{\mathrm{a}}$ & 860 & 0.0001 \\
\hline Organic matter (g/d) & $7569^{b}$ & 639 & $1829^{\mathrm{C}}$ & 80 & $13382^{a}$ & 815 & 0.0001 \\
\hline Crude protein $(\mathrm{N} \times 6.25)(\mathrm{g} / \mathrm{d})$ & $1011^{\mathrm{b}}$ & 61 & $179^{c}$ & 10 & $2255^{a}$ & 105 & 0.0001 \\
\hline Crude fibre $(\mathrm{g} / \mathrm{d})$ & $1910^{\mathrm{b}}$ & 121 & $732^{\mathrm{C}}$ & 39 & $3043^{a}$ & 191 & 0.0001 \\
\hline Energy (MJ ME/d) & $50 \cdot 9^{b}$ & $4 \cdot 2$ & $8 \cdot 8^{\mathrm{C}}$ & 0.4 & $94.5^{a}$ & $6 \cdot 2$ & 0.0001 \\
\hline
\end{tabular}

ME metabolisable energy; PDI, protein digestible in the intestine (Institut National de la Recherche Agronomique, 1989).

a,b,c Mean values with unlike superscript letters were significantly different $(P<0.05)$.

${ }^{*}$ For details of diets and procedures, see p. 618.

†Diets provided 130,21 or $237 \%$ maintenance energy requirements for control $(n 4)$ underfed $(n 4)$ and refed $(n 5)$ groups, respectively.

¥ Statistical significance of the nutritional status effect determined by the GLM procedure of SAS (SAS Institute Inc., Cary, NC, USA). 
100, Merck-Clévenot SA; Acid Acetic Kit, Boerhingher Mannheim, Meylan, France; TG (and non-esterified glycerol) GPO-trinder, Sigma, Saint-Quentin Fallavier, France; Urea UV test GIDH method, Merck-Clévenot SA; NEFA C WAkO, Unipath SA, Dardilly, France; Lactate PAP, BioMérieux, Marcy-l'Etoile, France), except for $\beta$-hydroxybutyrate, which was assayed as described by Barnouin et al. (1986).

\section{Adipose tissue and muscle measurements}

The FAS, G6PDH, ME and G3PDH activities were assayed spectrophotometrically in subcutaneous and perirenal AT as described previously (Chilliard et al. 1991).

LPL activity was measured in subcutaneous and perirenal $\mathrm{AT}$ and in CM and LT using an artificial emulsion containing $\left[{ }^{3} \mathrm{H}\right]$ triolein after a detergent (Deoxycholate-Nonidet P40; Sigma, Saint-Quentin-Fallavier, France) extraction procedure (Faulconnier et al. 1994).

Enzyme activities were expressed on a tissue weight basis, i.e. nmol released fatty acids (LPL) or nmol reduced (G6PDH, ME) or oxidised (FAS, G3PDH) nucleotides per min and per $\mathrm{g}$ tissue, or per total tissue (perirenal AT and $\mathrm{CM}$ ). Enzyme activities were also expressed on a cellular basis, i.e. nmol nucleotides per min and per $10^{6}$ adipocytes for AT or per $\mu \mathrm{g}$ DNA or per $\mathrm{mg}$ protein for AT and muscles, after measurement of adipocyte volume (Robelin, 1981), DNA content (Labarca \& Paigen, 1980) and soluble protein content in enzyme homogenates (Bradford, 1976).

Total RNA was extracted as described previously for AT (Bonnet et al. 1998) and CM (Hocquette et al. 1998). The levels of 3.4 plus $3.8 \mathrm{~kb}$ LPL mRNA were quantified by real-time quantitative RT-PCR in perirenal AT and CM, using the fluorescent TaqMan methodology and a 7700 Sequence Detector System (PE Applied Biosystems, Courtaboeuf, France) as described by Bonnet et al. (2000). The levels of LPL mRNA were related to the levels of cyclophilin mRNA, a housekeeping gene, measured by real time RT-PCR as described previously (Bonnet et al. 2000).

The GLUT4 protein contents in perirenal AT, CM and LT were quantified by immunoblotting using crude membranes as described by Hocquette et al. (1995). Briefly, crude membranes were prepared by differential centrifugation and then subjected to SDS-PAGE electrophoresis (12\% gel). GLUT4 protein was revealed using a polyclonal antibody raised against rat GLUT4 (James et al. 1989) and an anti-IgG antibody linked to horseradish (Armoracia rusticana) peroxidase (ECL Western Blotting Kit; Amersham, Les Ulis, France). Quantification was performed using a phosphoimager (Molecular Dynamic, Bondoufle, France) and the accompanying software. GLUT4 protein content was expressed on a cellular basis, i.e. as arbitrary densitometric units per $10^{6}$ adipocytes for AT or per $\mu \mathrm{g}$ DNA for muscles. To achieve this goal, GLUT4 protein content in crude membranes was first converted into units per $\mathrm{g}$ fresh tissue, taking into account protein yields in crude membranes. Although these yields differed between tissues, they did not differ between animal groups per tissue (results not shown), indicating that GLUT4 protein content in crude membranes was representative of that within the whole tissue, as previously described for calves (Hocquette et al. 2001).

\section{Statistical analysis}

Data were analysed using the GLM procedure of the SAS statistical package (SAS Institute Inc., Cary, NC, USA) with nutritional status as fixed effect. When applicable, the mean difference between groups was tested using the Student-Newman-Keuls test of GLM procedure. Differences between groups (control, underfed and refed) were considered to be significant when $P \leq 0 \cdot 05$.

\section{Results}

Body weight and condition score, tissue weight and cellularity, and plasma constituents

Empty body weight, body condition score, weights of perirenal AT and CM, and cellularities of perirenal AT, subcutaneous AT, CM and LT, were not significantly modified by nutritional status (Table 2).

Insulin and plasma metabolites, except lactate, were significantly modified by nutritional status (Table 3 ), although some differences depended on the time of blood collection. In samples collected at 14.00 hours, underfeeding ( $v$. control cows) decreased $(P<0.01)$ insulin $(-69 \%)$, acetate $(-90 \%)$, TG $(-72 \%)$, urea $(-44 \%)$ and 3-hydroxybutyrate $(-74 \%)$ levels, increased NEFA $(+506 \%, P<0.01)$ levels and had no effect on glucose, non-esterified glycerol and lactate concentrations. Conversely, refeeding ( $v$. underfed cows) increased $(P<0.01)$ insulin $(+147 \%)$, acetate $(+1650 \%)$, TG $(+125 \%)$, urea $(+154 \%)$ and 3-hydroxybutyrate $(+394 \%)$ levels, decreased NEFA $(-85 \%$, $P<0 \cdot 01)$ levels and had no effect on glucose, glycerol and lactate concentrations. In samples collected at 09.00 hours, similar variations in metabolite levels were observed (results not shown), except for 3-hydroxybutyrate and insulin, which were not modified by underfeeding and refeeding (Table 3), and for glucose, which was slightly increased by refeeding ( $+9 \% v$. underfed cows, $P<0 \cdot 05$; Table 3 ).

\section{Activities of enzymes involved in de novo lipogenesis and esterification}

In both perirenal and subcutaneous AT, the nutritional status modified the activities (expressed per $10^{6}$ adipocytes) of FAS, G6PDH and ME significantly $(P<0.05)$, but not of G3PDH, although a tendency was observed in perirenal AT (Fig. 1). Underfeeding ( $v$. control cows) had no effect, while refeeding ( $v$. underfed cows) increased $(P<0.05)$ the activity of FAS $(+243$ and $+133 \%$ in perirenal and subcutaneous AT respectively), G6PDH $(+307$ and $+89 \%)$ and $\mathrm{ME}(+296$ and $+79 \%)$ to levels significantly higher $(P<0.05)$ than those in the control group (Fig. 1). Similar effects were observed when the activities were expressed per $g$, per $\mu \mathrm{g}$ DNA or per mg protein in perirenal and subcutaneous AT, as well as per whole perirenal AT (results not shown).

\section{Lipoprotein lipase activity and $m R N A$ level}

The LPL activity, expressed on a per cell basis, was significantly modulated by nutritional status, in the same direction but with different amplitudes in AT and muscles 
Table 2. Effect of underfeeding and refeeding on bovine empty body weight, body condition score, perirenal and subcutaneous adipose tissues and cardiac and Longisimus thoracis muscle weight and cellularity*

(Mean values and standard deviations)

\begin{tabular}{|c|c|c|c|c|c|c|c|}
\hline \multirow{2}{*}{ Nutritional status...† } & \multicolumn{2}{|c|}{ Control } & \multicolumn{2}{|c|}{ Underfed } & \multicolumn{2}{|c|}{ Refed } & \multirow{2}{*}{$\begin{array}{c}\text { Statistical significance } \\
\text { of effect: } P \neq\end{array}$} \\
\hline & Mean & SD & Mean & SD & Mean & SD & \\
\hline Empty body weight $(\mathrm{kg}) \S$ & 635 & 67 & 691 & 83 & 709 & 67 & 0.23 \\
\hline Body condition score\|l & 3.13 & 0.66 & 3.31 & 0.24 & 3.50 & 0.18 & 0.41 \\
\hline \multicolumn{8}{|l|}{ Perirenal adipose tissue } \\
\hline Mass $(\mathrm{kg})$ & 9.03 & 1.60 & $9 \cdot 17$ & $2 \cdot 53$ & 11.04 & 3.94 & 0.54 \\
\hline Adipocyte number ( $10^{6}$ cells $/ \mathrm{g}$ tissue) & 1.05 & 0.31 & 1.26 & 0.52 & 0.90 & 0.27 & 0.40 \\
\hline DNA ( $\mu \mathrm{g} / \mathrm{g}$ tissue) & 824 & 126 & 885 & 192 & 749 & 207 & 0.55 \\
\hline Protein $(\mathrm{mg} / \mathrm{g}$ tissue) & $5 \cdot 12$ & 0.82 & 5.43 & 1.30 & 4.90 & 1.29 & 0.80 \\
\hline \multicolumn{8}{|l|}{ Subcutaneous adipose tissue } \\
\hline Adipocyte number $\left(10^{6} \mathrm{cells} / \mathrm{g}\right.$ tissue $)$ & 1.83 & 0.74 & 1.40 & 0.57 & 1.60 & 0.57 & 0.63 \\
\hline DNA ( $\mu \mathrm{g} / \mathrm{g}$ tissue) & 1181 & 351 & 1170 & 300 & 941 & 364 & 0.50 \\
\hline Protein (mg/g tissue) & $8 \cdot 84$ & $2 \cdot 37$ & $9 \cdot 82$ & $0 \cdot 80$ & $8 \cdot 83$ & 1.87 & 0.67 \\
\hline \multicolumn{8}{|l|}{ Cardiac muscle } \\
\hline Mass $(\mathrm{kg})$ & 3.04 & 0.51 & $2 \cdot 8$ & 0.41 & 2.9 & 0.21 & 0.57 \\
\hline DNA ( $\mu \mathrm{g} / \mathrm{g}$ tissue) & 2753 & 176 & 2853 & 222 & 2844 & 183 & 0.72 \\
\hline Protein (mg/g tissue) & 124 & 9 & 130 & 5 & 128 & 8 & 0.57 \\
\hline \multicolumn{8}{|l|}{ Longisimus thoracis muscle } \\
\hline DNA ( $\mu \mathrm{g} / \mathrm{g}$ tissue) & 2041 & 173 & 2059 & 313 & 1976 & 204 & 0.85 \\
\hline Protein (mg/g tissue) & 194 & 5 & 212 & 20 & 180 & 25 & 0.09 \\
\hline
\end{tabular}

${ }^{*}$ For details of diets and procedures, see Table 1 and p. 619.

†Diets provided 130,21 or $237 \%$ maintenance energy requirements for the control $(n 4)$ underfed $(n 4)$ and refed $(n 5)$ groups respectively.

$¥$ Statistical significance of the nutritional status effect determined by the GLM procedure of SAS (SAS Institute Inc., Cary, NC, USA).

$\S$ Empty body weight is body weight minus weight of digestive content.

\| Body condition score estimated on a scale of 0 to 5 .

(Fig. 2). Underfeeding ( $v$. control cows) decreased $(P<0.05)$ CM-LPL $(-67 \%)$ and perirenal AT-LPL $(-70 \%)$ but not subcutaneous AT- and LT-LPL activities. Refeeding ( $v$. underfed cows) increased $(P<0.05)$ LPL activity in both AT (perirenal AT $+553 \%$, subcutaneous $\mathrm{AT}+212 \%)$ and muscles $(\mathrm{CM}+250 \%$, $\mathrm{LT}+41 \%)$ to levels comparable in CM, or greater in AT and LT than those observed in the control group. Similar effects were observed when LPL activity was expressed per $g$, per $\mu \mathrm{g}$
DNA, per mg protein of the four tissues or per whole tissue for perirenal AT and CM (results not shown).

LPL mRNA levels were not significantly modulated by nutritional status in perirenal AT and CM (Fig. 3).

\section{GLUT4 protein content}

GLUT4 protein content, expressed on a per cell basis, was significantly modified by nutritional status in perirenal AT

Table 3. Effect of underfeeding and refeeding on plasma metabolites and insulin in cows*

(Mean values and standard deviations)

\begin{tabular}{|c|c|c|c|c|c|c|c|}
\hline \multirow{2}{*}{ Nutritional status...† } & \multicolumn{2}{|c|}{ Control } & \multicolumn{2}{|c|}{ Underfed } & \multicolumn{2}{|c|}{ Refed } & \multirow{2}{*}{$\begin{array}{c}\text { Statistical significance } \\
\text { of effect: } P \neq\end{array}$} \\
\hline & Mean & SD & Mean & SD & Mean & SD & \\
\hline 09.00 hours & 75 & 34 & 53 & 19 & 74 & 34 & 0.36 \\
\hline 14.00 hours & $150^{A}$ & 49 & $47^{\mathrm{B}}$ & 12 & $116^{\mathrm{A}}$ & 28 & 0.003 \\
\hline \multicolumn{8}{|l|}{ Plasma metabolites } \\
\hline \multicolumn{8}{|l|}{ Glucose (mM) } \\
\hline 09.00 hours & $3.56^{b}$ & 0.16 & $3.56^{b}$ & 0.23 & $3 \cdot 88^{a}$ & 0.07 & 0.01 \\
\hline 14.00 hours & $3 \cdot 31$ & 0.32 & $3 \cdot 76$ & 0.36 & 3.27 & 0.31 & 0.07 \\
\hline Acetate $(\mu \mathrm{M}) \S$ & $640^{\mathrm{B}}$ & 25 & $60^{C}$ & 3 & $1050^{A}$ & 140 & 0.001 \\
\hline Triacylglycerol $(\mu \mathrm{M}) \S$ & $113^{\mathrm{A}}$ & 9 & $32^{C}$ & 18 & $72^{\mathrm{B}}$ & 27 & 0.0001 \\
\hline Urea $(\mathrm{mm}) \S$ & $4.41^{\mathrm{B}}$ & 0.61 & $2 \cdot 49^{C}$ & 0.92 & $6 \cdot 32^{A}$ & 1.01 & 0.0001 \\
\hline \multicolumn{8}{|l|}{ 3-hydroxybutyrate $(\mu \mathrm{M})$} \\
\hline 09.00 hours & 155 & 61 & 189 & 106 & 246 & 113 & 0.41 \\
\hline 14.00 hours & $562^{\mathrm{A}}$ & 165 & $144^{\mathrm{B}}$ & 27 & $712^{A}$ & 84 & 0.001 \\
\hline $\operatorname{NEFA}(\mu \mathrm{M}) \S$ & $68^{\mathrm{B}}$ & 31 & $412^{A}$ & 74 & $63^{\mathrm{B}}$ & 19 & 0.001 \\
\hline Lactate $(\mathrm{mm}) \S$ & 1.08 & 0.70 & $1 \cdot 17$ & 0.74 & 0.67 & 0.12 & 0.40 \\
\hline
\end{tabular}

Mean values within a row with unlike superscript letters were significantly different ${ }^{\mathrm{a}, \mathrm{b}, \mathrm{c}} P<0.05,{ }^{\mathrm{A}, \mathrm{B}, \mathrm{C}} P<0.01$.

${ }^{*}$ For details of diets and procedures, see Table 1 and p. 618 .

†Diets provided 130,21 or $237 \%$ maintenance energy requirements for the control $(n 4)$ underfed $(n 4)$ and refed $(n 5)$ groups respectively.

$\ddagger$ Statistical significance of the nutritional status effect determined by the GLM procedure of SAS (SAS Institute Inc., Cary, NC, USA).

$\S$ Plasma concentrations assayed in samples collected at 14.00 hours. 

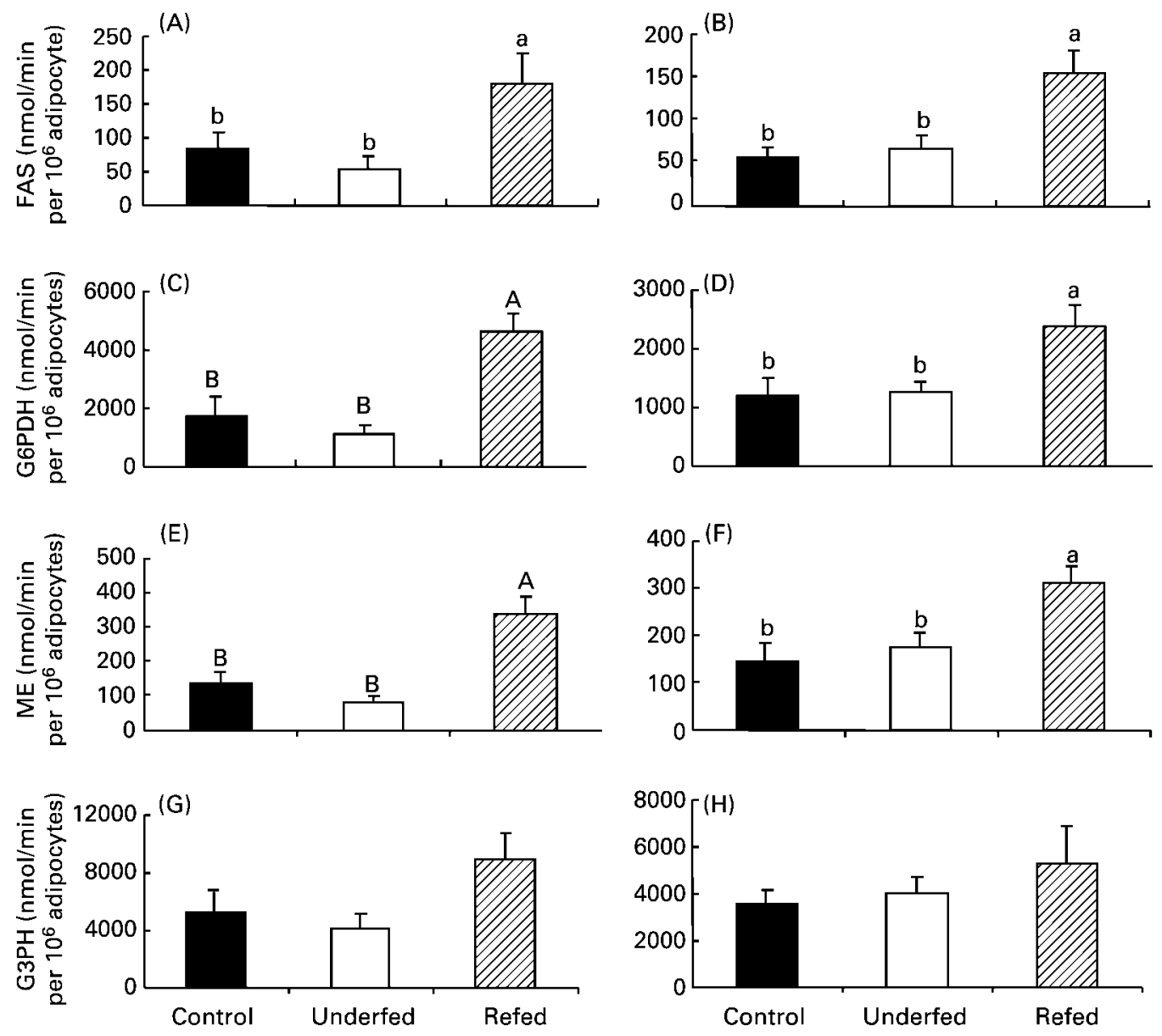

Fig. 1. Effect of nutritional status on activities (nmol/min per $10^{6}$ adipocytes) of fatty acid synthase (FAS, (A) and (B)), glucose-6-phosphate dehydrogenase (G6PDH, (C) and (D)), malic enzyme (ME, $(E)$ and $(F)$ ) and glycerol-3-phosphate dehydrogenase $(G 3 P D H,(G)$ and $(H))$ in perirenal ((A), (C), (E), (G)) and subcutaneous ((B), (D), (F), (H)) adipose tissue from control $(n 4)$, underfed $(n 4)$ and refed $(n 5)$ cows. For details of diets and procedures, see Table 1 and p. 619. Values are means with standard deviations shown by vertical bars. Mean values with unlike superscript letters were significantly different: ${ }^{a, b} P<0.05,{ }^{A}, B P<0.01$. Statistical significance of effect of nutritional status (GLM procedure of SAS (SAS Institute Inc., Cary, NC, USA)): (A) $P=0.05$, (B) $P=0.01$, (C) $P=0.004$, (D) $P=0.05$, (E) $P=0.003$, (F) $P=0.009$, (G) $P=0.12$, (H) $P=0.56$.
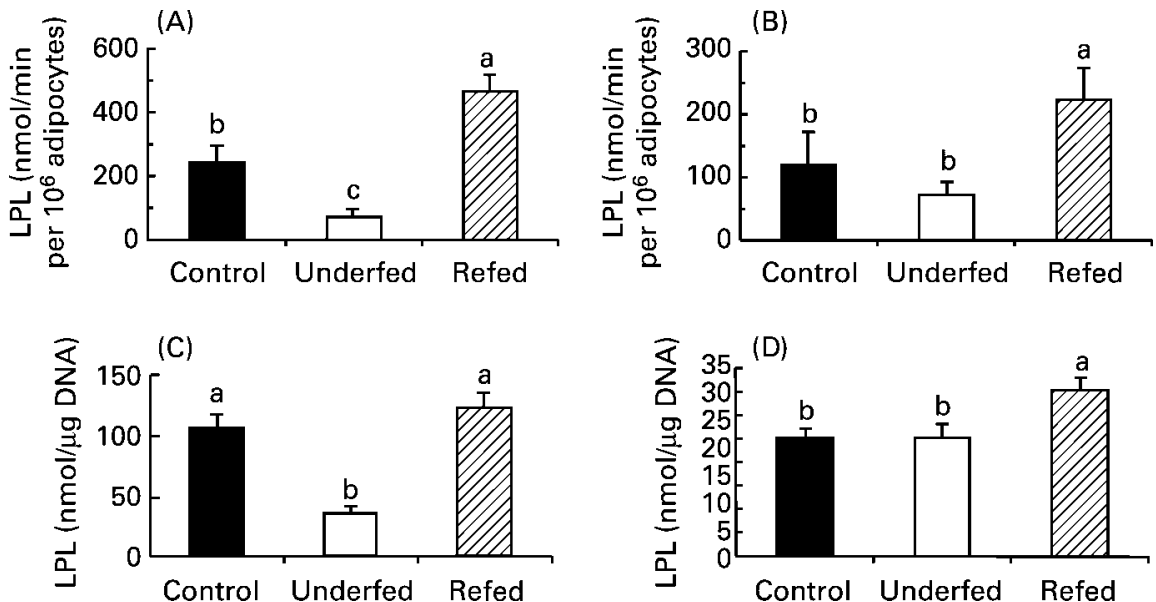

Fig. 2. Effect of nutritional status on lipoprotein lipase (LPL) activity in perirenal (A) and subcutaneous (B) adipose tissues and in cardiac (C) and Longisimus thoracis (D) muscles from control $(n 4)$, underfed $(n 4)$ and refed $(n 5)$ cows. For details of diets and procedures, see Table 1 and p. 619. Values are means with standard deviations shown by vertical bars. Mean values with unlike superscript letters were significantly different: ${ }^{\mathrm{a}, \mathrm{b}, \mathrm{c}} P<0.05$. Statistical significance of effect of nutritional status (GLM procedure of SAS (SAS Institute Inc., Cary, NC, USA)): (A) $P=0.0006$, (B) $P=0.05$, (C) $P=0.002$, (D) $P=0.05$. 
(A)

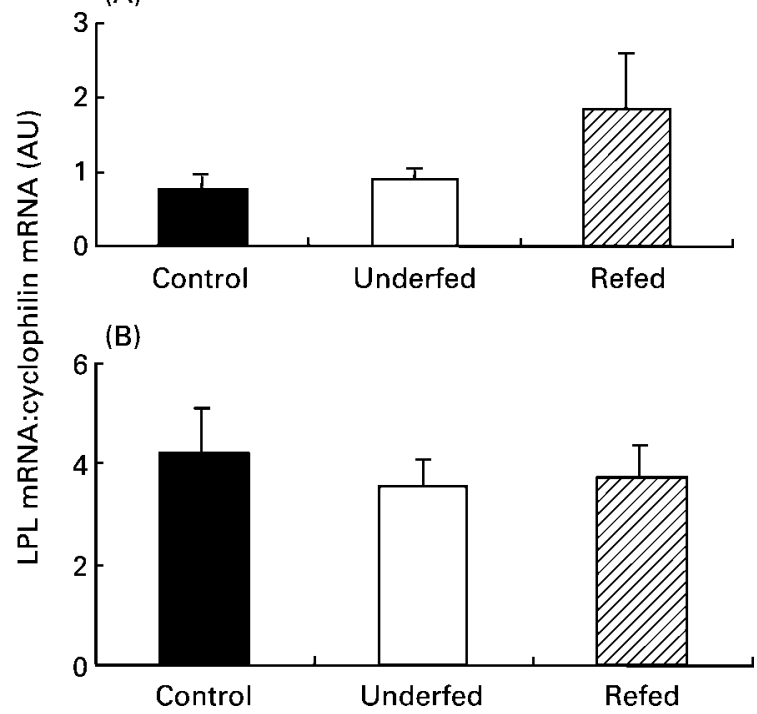

Fig. 3. Effect of nutritional status on lipoprotein lipase (LPL) mRNA levels determined using a real-time quantitative RT-PCR protocol. LPL and cyclophilin mRNA levels were measured in (A) perirenal adipose tissue and in (B) cardiac muscles from control $(n 4)$, underfed $(n 4)$ and refed $(n 5)$ cows in order to calculate the LPL:cyclophilin mRNA ratio. AU, arbitrary units. For details of diets and procedures, see Table 1 and p. 619. Values are means with standard deviations shown by vertical bars. Statistical significance of effect of nutritional status (GLM procedure of SAS (SAS Institute Inc., Cary, NC, USA)): (A) $P=0.24$, (B) $P=0.83$.

( $P=0.04)$, and tended to be modified in CM $(P=0.09)$, but not in LT (Fig. 4). In perirenal AT underfeeding ( $v$. control cows) had no effect, while refeeding ( $v$. underfed cows) increased $(+250 \%, P<0.05)$ GLUT4 protein content (Fig. 4)

\section{Discussion}

\section{General effects of nutritional status}

The mid-term (1-2 weeks) nutritional treatments were too short to induce significant variations in empty body weight, AT and CM weights and cellularity, but were sufficient to induce the expected variations in plasma metabolites and insulin levels during underfeeding and refeeding in ruminant animals (for review, see Chilliard et al. 1995). Underfeeding increased plasma NEFA arising from fat mobilisation and decreased plasma insulin and metabolite levels resulting from food digestion, i.e. acetate, TG and urea, as well as postprandial (14.00 hours) 3-hydroxybutyrate arising from ruminal ketogenesis (dietary origin; Chilliard et al. 1995). Refeeding restored these plasma values. Underfeeding and refeeding did not have the same effect on preprandial (09.00 hours) and postprandial (14.00 hours) values of plasma insulin and glucose, which could result from an additional within-day effect of meal intake. The levels of postprandial insulin were higher than preprandial values in control and refed cows, probably as a result of response to meal intake, which did not occur in underfed cows, as described previously (Delavaud et al. 2002). Hence, meal intake could have exacerbated the effect of feeding level on postprandial insulinaemia.
(A)
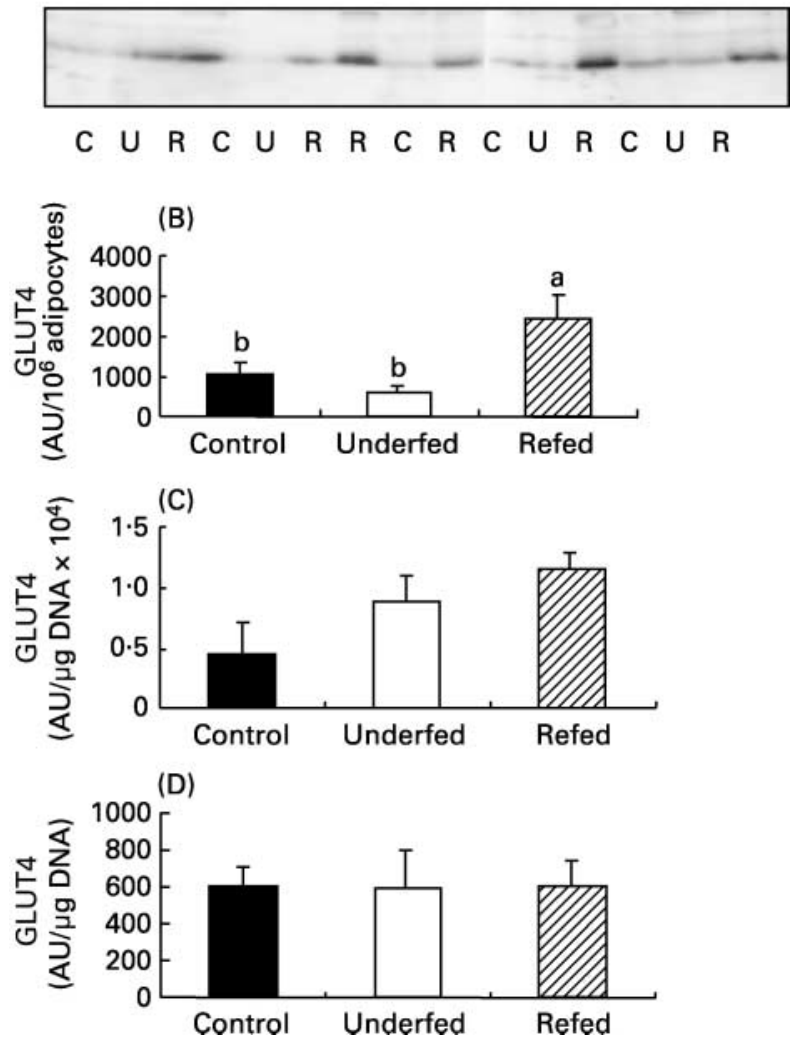

Fig. 4. Effect of nutritional status on GLUT4 protein content in perirenal adipose (A, B) tissue and in cardiac (C) and Longisimus thoracis (D) muscles from control $(n 4)$, underfed $(n 4)$ and refed $(n 5)$ cows. (A), a representative Western blot analysis of GLUT4 protein content in perirenal adipose tissue. The protein has a molar mass of $42-45 \mathrm{kDa}$. (B), (C), (D), GLUT4 protein content quantified by densitometric analysis of Western blot in perirenal adipose tissue and in cardiac and Longisimus thoracis muscles. AU, arbitrary units. For details of diets and procedures, see Table 1 and p. 619. Values are means with standard deviations shown by vertical bars. Mean values with unlike superscript letters were significantly different: ${ }^{a, b} P<0.05$. Statistical significance of effect of nutritional status (GLM procedure of SAS (SAS Institute Inc., Cary, NC, USA)): (B) $P=0.04$, (C) $P=0.09$, (D) $P=0.99$.

By contrast, the effect of underfeeding and refeeding on postprandial values of plasma glucose could have been masked by the effect of meal intake. Delavaud et al. (2002) reported that meal intake decreased glycaemia in control and refed cows and increased it in underfed cows.

Refeeding increased activities of enzymes involved in de novo lipogenesis

Our present results on bovine AT complement previous studies in ruminant animals (Young et al. 1969; Ingle et al. 1973; Martin et al. 1973; Pothoven \& Beitz, 1973, 1975; Smith et al. 1983) reporting a lack of variation or a decrease in the activities of enzymes involved in fatty acid synthesis during a $2-8 \mathrm{~d}$ fast and an increase during an $8-56 \mathrm{~d}$ refeeding regimen.

The lack of variation in the activities of FAS, G6PDH, $\mathrm{ME}$ and G3PDH in cows underfed for $7 \mathrm{~d}$ is in agreement with previous results for the activities of FAS (Ingle et al. 1973) and NADP-generating enzymes in fattening lambs 
fasted for $2 \mathrm{~d}$ and in steers fasted for $4-8 \mathrm{~d}$ (Young et al. 1969; Smith et al. 1983). However, our present results contrast with the decrease in the activities of FAS and NADPgenerating enzymes observed in steers and lambs fasted for $8 \mathrm{~d}$ (Martin et al. 1973; Pothoven \& Beitz, 1975) or $21 \mathrm{~d}$ (Pothoven \& Beitz, 1973). Such variability in the response of enzymes involved in de novo lipogenesis during fasting could be a result of the buffering role of the rumen and/or diet composition. Indeed, the lack of variation during short- or mid-term food deprivation could be explained by the high number of days required to reach a fasted state due to the buffering effect of the rumen, e.g. in growing steers, 4 and $8 \mathrm{~d}$ of fasting are required to achieve minimum activities for FAS and G6PDH respectively (Pothoven \& Beitz, 1975). In addition, one could hypothesise that an even longer period of underfeeding would be required, especially if the control diet provided $130 \%$ metabolisable energy requirement, as in the present study. Moreover, the roughage:concentrate ratio in the diet before fasting has been shown to induce variations in the response of the lipogenic activity: the grester the proportion of concentrate, the greater the changes in enzyme activities (Martin et al. 1973; Vernon, 1980). Taken together, these studies highlight the notion that the amplitude of the variation in enzyme activities during food deprivation depends not only on the duration and level of underfeeding, but also on the quality of the diet before food deprivation.

Refeeding $7 \mathrm{~d}$ underfed cows for $21 \mathrm{~d}$ increased the activities of FAS, G6PDH and ME in AT, as was observed in $7 \mathrm{~d}$ underfed ewes refed for $14 \mathrm{~d}$ (Bocquier et al. 1998; Faulconnier et al. 2001) and in $10 \mathrm{~d}$ underfed cows refed for $21 \mathrm{~d}$ (Bonnet et al. 1998). Similar increases were observed for FAS (Smith et al. 1983), G6PDH and ME (Pothoven \& Beitz, 1975) activities in $4 \mathrm{~d}$ fasted steers refed for 14 or $20 \mathrm{~d}$. These increases could result from both the level of refeeding and the proportion of concentrate in the diet of the refed group, because propionate is probably the major trigger for the secretion of insulin. During refeeding, the increase in G3PDH activity was not statistically significant in perirenal or subcutaneous AT, contrary to what we previously observed in ewes (Bocquier et al. 1998; Faulconnier et al. 2001) and cows (Bonnet et al. 1998). The difference in G3PDH response to refeeding, together with its high level of activity in all feeding conditions, suggests that G3PDH activity is not rapidly modified and that its levels are not rate-limiting in esterification.

\section{Underfeeding tended to decrease and refeeding increased lipoprotein lipase activity through post-transcriptional mechanisms}

Our present results on LPL activity (especially in perirenal AT and CM) are in agreement with previous studies (Chilliard et al. 1979; DiMarco et al. 1981; Tume et al. 1983; Bonnet et al. 1998, 2000; Faulconnier et al. 2001) reporting that ruminant animal AT-LPL activity is down-regulated by underfeeding and up-regulated by refeeding. They also confirm that nutritional status regulates muscle LPL in the same direction as AT-LPL activity, as we first observed in ewes (Bonnet et al. 2000; Faulconnier et al. 2001). The lack of a significant decrease in LPL activities in subcutaneous AT and in LT in the present study could be explained by a number of factors: the short duration of underfeeding, as discussed for lipogenic enzymes; the lower activities that may be more difficult to modify than in perirenal AT and $\mathrm{CM}$; or finally, a lower sensitivity of these tissues to insulin or other hormones and metabolites involved in the mediation of dietary actions. Furthermore, changes in perirenal AT- and CMLPL activities in the absence of any change in LPL mRNA levels suggest a post-transcriptional regulation of the LPL gene. By contrast, we previously observed a pre-translational regulation in 7 or $8 \mathrm{~d}$ underfed ewes refed for 10 or $14 \mathrm{~d}$ (Bonnet et al. 1998, 2000; Faulconnier et al. 2001). These results suggest that LPL may be regulated by different mechanisms in different ruminant animal species and/or may result from differences in the duration of nutritional treatments, as reported in rodents. In rats, short- and mid-term variations in nutritional status regulate LPL at a post-transcriptional level by modulating specific activity and protein content, while in midand long-term experiments LPL was regulated at a pretranslational level by modulating mRNA level (Ladu et al. 1991; Bergö et al. 1996a,b; Lee et al. 1998).

Underfeeding cows down-regulates LPL activity, whereas refeeding up-regulates LPL activity, in oxidative muscles, as we first observed in ewes (Bonnet et al. 2000). The present results in cows support our previous hypothesis suggesting that differences between ruminant animals and rodents in the nutritional regulation of muscle LPL activity are probably related to the specificity of ruminant animals for nutrient digestion and absorption, and liver lipogenesis (Bonnet et al. 2000). The low capacity of ruminant animal liver to synthesise fatty acids and to secrete TG may minimise the recycling of plasma NEFA mobilised from AT during underfeeding as TG-rich lipoproteins in the liver. In agreement with this, plasma TG decreased substantially in underfed ewes (Bonnet et al. 2000) and cows (Table 3) and decreased slightly (Sugden et al. 1993) or remained unchanged (Björntorp et al. 1982) in fasted rats, allowing the maintenance of substrate availability for muscle LPL in rats, but not in ewes and cows. Moreover, our present results for cows support an earlier study (Bonnet et al. 2000) in which we reported a striking correlation across animal species between the response of CM-LPL activity to starvation or underfeeding and hepatic ability to secrete TG. This correlation accounts for a direct or indirect link between the nature of the available energy substrates and interspecies differences in the nutritional regulation of muscle LPL.

\section{Underfeeding had no effect and refeeding increased GLUT4 protein content in adipose tissue but not in muscles}

Our present results on GLUT4 expression in CM, LT and perirenal AT cannot be extrapolated to all muscles and AT, since a tissue-specific regulation of GLUT4 expression was demonstrated in cattle (Hocquette et al. 2001). However, the studied tissues represent the major insulinsensitive tissue types of the body. 
During underfeeding, our present results contrast with the decrease in GLUT4 protein content previously reported in AT and glycolytic muscle from ewes restricted to $60 \%$ metabolisable energy requirement for 2-3 weeks during late pregnancy (Bell \& Bauman, 1997). Such a discrepancy could be related to the short duration of our underfeeding period and/or to tissue-specific regulation of GLUT4 and/ or to difference in physiological status. Bell \& Bauman (1997) have reviewed results suggesting that pregnancy results in insulin resistance characterised by a down-regulation of insulin sensitivity and glucose utilisation by peripheral tissues, and thus GLUT4 content, in order to spare glucose and ensure a glucose supply to the conceptus preferentially. During refeeding, GLUT4 content increased in bovine AT, as in rats (for review, see Kahn, 1994). However, the lack of variation of GLUT4 content both in CM and LT contrasts with the increase reported in heart (Woloschak et al. 1993) and the decrease generally observed in skeletal muscles (Woloschak et al. 1993; Kahn, 1994) from refed rats.

Differing regulation of muscle GLUT4 expression between ruminant animals and rats was not only observed during pregnancy in ewes (Bell \& Bauman, 1997), but also during lactation in goats (Balage et al. 1997) and at weaning in calves (Hocquette et al. 2001). Our present results in underfed-refed cows show that nutritional status per se is also a factor, which could interact with such physiological factors to induce species-specific regulation of muscle GLUT4 expression. Such interspecies differences in the nutritional regulation of muscle GLUT4 expression may be of experimental origin (duration and intensity of nutritional experiments) or due to different levels of regulation (pre- or post-translational level) or more probably related to the lower variations in plasma glucose from underfedrefed cows than from fasted-refed rats. Indeed, the major factors in regulation of GLUT4 were shown to be glucose supply and the associated changes in the insulin-glucose axis, which are strongly altered in rats during nutritional experiments (for review, see Kahn, 1994). Consequently, the lack of differences in preprandial concentrations of plasma glucose and insulin in underfed ( $v$. control) cows (Table 3) could explain the lack of variation of GLUT4 protein contents in AT and muscles. Furthermore, the small changes in plasma glucose and insulin levels in refed ( $v$. underfed) cows (Table 3) were probably great enough to regulate GLUT4 expression in AT but not in muscles.

The mechanisms that mediate dietary actions remain to be identified, especially in ruminant animals. In muscles, they are probably different from those involved either in rats due to the species difference, or in AT due to the tissuespecific response of GLUT4 protein content. One could hypothesise that these mechanisms in bovine muscles arise from the digestive and metabolic specificities of ruminant animals (for review, see Hocquette \& Abe, 2000), e.g. unlike rat muscles, bovine oxidative muscles consume more volatile fatty acids (acetate) than glucose and this may form the basis of ruminant-specific regulation of GLUT4 expression. In AT, the concomitant increases in GLUT4 content and in plasma insulin with refeeding suggest that dietary actions may be mediated, at least in part, by insulin in cattle, as in rats (for review, see Kahn, 1994).

\section{Conclusion}

The present study shows that mid-term variations in nutritional status, and especially refeeding underfed cows, induce adaptations in the lipogenic activity (de novo lipogenesis and hydrolysis of plasma TG) and in GLUT4 content in AT, as well as in the hydrolysis of plasma TG by muscles. Furthermore, the adaptations were greater in perirenal than subcutaneous AT and in oxidative than glycolytic muscles. We confirm that, in ruminant animals, ATLPL and muscle LPL are regulated in the same direction contrary to the situation in rats and may be related to species differences in the liver's ability to synthesise and to secrete fatty acids as TG-rich lipoproteins. The present results suggest that periods of lipid storage in AT are accompanied by an increase in LPL activity in muscles, which accounts for the involvement of this enzyme in the availability of long-chain fatty acids as substrates in intramuscular lipid deposition and as an energy source in protein accretion. Moreover, we show that GLUT4 content in muscles from cows was unchanged by variations in nutritional status, contrary to what was observed in rats. These different effects of nutritional status between cows and rats could partly explain previously observed species differences in muscle GLUT4 expression and glucose metabolism linked to differences in physiological status. Such species differences may help to identify the mechanisms, as well as the mediators, involved in nutritional regulation of muscle GLUT4 expression, assuming that they are the same but differentially regulated, depending on the animal species. It may be of practical importance to control GLUT4 expression in AT and muscles, and thus glucose partitioning between these cell types, to favour milk production in lactating animals on the one hand, and to control protein and intramuscular fat accretions in meat-producing animals on the other.

\section{Acknowledgements}

We thank A. Ollier, J. P. Pezant and their team for the management of the animals, and G. Cuylle and his team for slaughtering the animals; J. Fléchet and N. Guivier for lipogenic enzymes assays, total RNA extraction, GLUT4 Western blot and DNA measurement; M. Tourret for adipocyte volume and plasma insulin and metabolites measurements. This work was supported by an INRA grant for studies on lipogenesis in farm animals.

\section{References}

Balage M, Hocquette JF, Graulet B, Ferré P \& Grizard J (1997) Skeletal muscle glucose transporter (GLUT-4) protein is decreased in lactating goats. Anim Sci 65, 257-265.

Barnouin J, El Idilbi N, Chilliard Y, Chacornac JP \& Lefaivre R (1986) Micro-dosage automatisé sans déprotéinisation du 3hydroxybutyrate plasmatique chez les bovins (An automated micro-method for the determination of 3-hydroxybutyrate in bovine plasma without acid precipitation). Ann Rech Vet 17, 129-139.

Bell AW \& Bauman DE (1997) Adaptations of glucose metabolism during pregnancy and lactation. J Mammary Gland Biol Neoplasia 2, 265-278.

Bergö M, Olivecrona G \& Olivecrona T (1996a) Diurnal rhythms 
and effects of fasting and refeeding on rat adipose tissue lipoprotein lipase. Am J Physiol 271, E1092-E1097.

Bergö M, Olivecrona G \& Olivecrona T (1996b) Forms of lipoprotein lipase in rat tissues: in adipose tissue the proportion of inactive lipase increases on fasting. Biochem J 313, 893-898.

Björntorp P, Edström S, Kral JG, Lundholm K, Presta E, Walks D \& Yang MU (1982) Refeeding after fasting in the rat: energy substrate fluxes and replenishment of energy stores. Am J Clin Nutr 36, 450-456.

Bocquier F, Bonnet M, Faulconnier Y, Guerre-Millo M, Martin P \& Chilliard Y (1998) Effects of photoperiod and feeding level on perirenal adipose tissue metabolic activity and leptin synthesis in the ovariectomized ewe. Reprod Nutr Dev 38, 489-498.

Bonnet M, Faulconnier Y, Fléchet J, Hoquette JF, Levoux C, Langin D, Martin P \& Chilliard Y (1998) Messenger RNAs encoding lipoprotein lipase, fatty acid synthase and hormonesensitive lipase in the adipose tissue of underfed-refed ewes and cows. Reprod Nutr Dev 38, 297-307.

Bonnet M, Leroux C, Faulconnier Y, Hocquette JF, Bocquier F, Martin P \& Chilliard Y (2000) Lipoprotein lipase activity and mRNA are up-regulated by refeeding in adipose tissue and cardiac muscle of sheep. J Nutr 130, 749-756.

Bradford MM (1976) A rapid and sensitive method for the quantitation of microgram quantities of protein utilizing the principle of protein-dye binding. Anal Biochem 72, 248-254.

Chilliard Y, Doreau M, Bocquier F \& Lobley GE (1995) Recent developments in nutrition of herbivores. In Proceedings of the IVth International Symposium on the Nutrition of Herbivores, pp. 329-360 [M Journet, E Grenet, MH Farce, M Thériez and C Demarquilly, editors]. Paris: INRA Editions.

Chilliard Y, Ferlay A, Faulconnier Y, Bonnet M, Rouel J \& Bocquier F (2000) Adipose tissue metabolism and its role in adaptations to undernutrition in ruminants. Proc Nutr Soc 59, 127-134.

Chilliard Y, Gagliostro G, Fléchet J, Lefaivre R \& Sebastian I (1991) Duodenal rapeseed oil infusion in early and midlactation cows. 5. Milk fatty acid and adipose tissue lipogenic activities. J Dairy Sci 74, 1844-1854.

Chilliard Y, Sauvant D \& Morand-Fehr P (1979) Goat mammary, adipose and milk lipoprotein lipases. Ann Rech Vet 10, 401-403.

Delavaud C, Ferlay A, Faulconnier Y, Bocquier F, Kann G \& Chilliard Y (2002) Plasma leptin concentration in adult cattle: effects of breed, adiposity, feeding level, and meal intake. J Anim Sci 80, 1317-1328.

DiMarco NM, Bietz DC \& Whitehurst GB (1981) Effect of fasting on free fatty acid, glycerol and cholesterol concentrations in blood plasma and lipoprotein lipase activity in adipose tissue of cattle. J Anim Sci 52, 75-82.

Faulconnier Y, Bonnet M, Bocquier F, Leroux C \& Chilliard Y (2001) Effects of photoperiod and feeding level on adipose tissue and muscle lipoprotein lipase activity and mRNA level in dry non-pregnant sheep. Br J Nutr 85, 299-306.

Faulconnier Y, Thévenet M, Fléchet J \& Chilliard Y (1994) Lipoprotein lipase and metabolic activities in incubated bovine adipose tissue explants: effects of insulin, dexamethasone, and fetal bovine serum. J Anim Sci 72, 184-191.

Ferlay A \& Chilliard Y (1999) Effects of the infusion of nonselective beta-, and selective beta1- or beta2-adrenergic agonists, on body fat mobilisation in underfed or overfed non-pregnant heifers. Reprod Nutr Dev 39, 409-421.

Hocquette JF \& Abe H (2000) Facilitative glucose transporters in livestock species. Reprod Nutr Dev 40, 517-533.

Hocquette JF, Bornes F, Balage M, Ferre P, Grizard J \& Vermorel M (1995) Glucose-transporter (GLUT4) protein content in oxidative and glycolytic skeletal muscles from calf and goat. Biochem J 305, 465-470.
Hocquette JF, Graulet B \& Olivecrona T (1998) Lipoprotein lipase activity and mRNA levels in bovine tissues. Comp Biochem Physiol 121, 85-96.

Hocquette JF, Graulet B, Vermorel M \& Bauchart D (2001) Weaning affects lipoprotein lipase activity and gene expression in adipose tissues and in masseter but not in other muscles of the calf. Br J Nutr 86, 433-441.

Ingle DL, Bauman DE, Mellenberger RW \& Johnson DE (1973) Lipogenesis in the ruminant: effect of fasting and refeeding on fatty acid synthesis and enzymatic activity of sheep adipose tissue. J Nutr 103, 1479-1488.

Institut National de la Recherche Agronomique (1989) Ruminant Nutrition, Recommended Allowances and Feed Tables [R Jarrige, editor]. Paris: John Libley Eurotext.

James DE, Strube M \& Mueckler M (1989) Molecular cloning and characterization of an insulin-regulatable glucose transporter. Nature 338, 83-87.

Kahn BB (1994) Dietary regulation of glucose transporter gene expression: tissue specific effects in adipose cells and muscle. $J$ Nutr 124, 1289S-1295S.

Labarca C \& Paigen KA (1980) Simple, rapid, sensitive DNA assay procedure. Anal Biochem 102, 344-352.

Ladu MJ, Kapsas H \& Palmer WK (1991) Regulation of lipoprotein lipase in adipose and muscle tissues during fasting. Am J Physiol 260, R953-R959.

Lee JJ, Smith JP \& Fried SK (1998) Mechanisms of decreased lipoprotein lipase activity in adipocytes of starved rats depend on duration of starvation. J Nutr 128, 940-946.

Martin RJ, Wilson LL, Cowan RL \& Sink JD (1973) Effects of fasting and diet on enzyme profiles in ovine liver and adipose tissue. J Anim Sci 36, 101-106.

Pethick DW (1984) Energy metabolism of skeletal muscle. In Proceedings of the Symposium on Ruminant Physiology: Concepts and Consequences, pp. 277-287 [SK Baker, JM Gawthorne, JB Mackintosh and DB Purser, editors]. Nedlands: University of Western Australia.

Pothoven MA \& Beitz DC (1975) Changes in fatty acid synthesis and lipogenic enzymes in adipose tissue from fasted and fasted-refed steers. J Nutr 105, 1055-1061.

Pothoven MA \& Beitz DC (1973) Effect of adipose tissue site, animal weight, and long-term fasting on lipogenesis in the bovine. J Nutr 103, 468-475.

Quig DW, Layman DK, Bechtel PJ \& Hackler LR (1983) The influence of starvation and refeeding on the lipoprotein lipase activity of skeletal muscle and adipose tissue of lean and obese Zucker rats. J Nutr 113, 1150-1156.

Robelin J (1981) Cellularity of bovine adipose tissue: developmental changes from 15 to 65 percent mature weight. J Lipid Res 22, 452-457.

Smith SB, Prior RL \& Mersmann HJ (1983) Interrelationships between insulin and lipid metabolism in normal and alloxandiabetic cattle. J Nutr 113, 1002-1015.

Sugden MC, Holness MJ \& Howard RM (1993) Changes in lipoprotein lipase activities in adipose tissue, heart and skeletal muscle during continuous or interrupted feeding. Biochem $J$ 292, 113-119.

Tume RK, Thornton RF \& Johnson GW (1983) Lipoprotein lipase of sheep and rat adipose tissues. Aust J Biol Sci 36, 41-48.

Vernon RG (1980) Lipid metabolism in the adipose tissue of ruminant animals. Prog Lipid Res 19, 23-106.

Woloschak M, Shen-Orr Z, LeRoith D \& Roberts CT Jr (1993) Nutritional regulation of insulin-sensitive glucose transporter gene expression in rat cardiac muscle. Proc Soc Exp Biol Med 203, 172-174.

Young JW, Thorp SL \& De Lumen HZ (1969) Activity of selected gluconeogenic and lipogenic enzymes in bovine rumen mucosa, liver and adipose tissue. Biochem J 114, 83-88. 